\title{
Growing season methane emission from a boreal peatland in the continuous permafrost zone of Northeast China: effects of active layer depth and vegetation
}

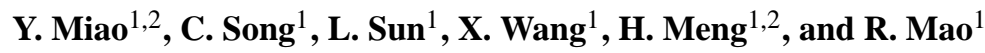 \\ ${ }^{1}$ Northeast Institute of Geography and Agroecology, Chinese Academy of Sciences, Changchun, Jilin, China \\ ${ }^{2}$ Graduate University of Chinese Academy of Sciences, Beijing, China \\ Correspondence to: C. C. Song (songcc@neigae.ac.cn)
}

Received: 20 April 2012 - Published in Biogeosciences Discuss.: 12 June 2012

Revised: 12 October 2012 - Accepted: 20 October 2012 - Published: 13 November 2012

\begin{abstract}
Boreal peatlands are significant natural sources of methane and especially vulnerable to abrupt climate change. However, the controlling factors of $\mathrm{CH}_{4}$ emission in boreal peatlands are still unclear. In this study, we investigated $\mathrm{CH}_{4}$ fluxes and abiotic factors (temperature, water table depth, active layer depth, and dissolved $\mathrm{CH}_{4}$ concentrations in pore water) during the growing seasons in 2010 and 2011 in both shrub-sphagnum- and sedge-dominated plant communities in the continuous permafrost zone of Northeast China. The objective of our study was to examine the effects of vegetation types and abiotic factors on $\mathrm{CH}_{4}$ fluxes from a boreal peatland. In an Eriophorum-dominated community, mean $\mathrm{CH}_{4}$ emissions were 1.02 and $0.80 \mathrm{mg} \mathrm{m}^{-2} \mathrm{~h}^{-1}$ in 2010 and 2011, respectively. $\mathrm{CH}_{4}$ fluxes $\left(0.38 \mathrm{mg} \mathrm{m}^{-2} \mathrm{~h}^{-1}\right)$ released from the shrub-mosses-dominated community were lower than that from Eriophorum-dominated community. Moreover, in the Eriophorum-dominated community, $\mathrm{CH}_{4}$ fluxes showed a significant temporal pattern with a peak value in late August in both 2010 and 2011. However, no distinct seasonal variation was observed in the $\mathrm{CH}_{4}$ flux in the shrubmosses-dominated community. Interestingly, in both Eriophorum- and shrub-sphagnum-dominated communities, $\mathrm{CH}_{4}$ fluxes did not show close correlation with air or soil temperature and water table depth, whereas $\mathrm{CH}_{4}$ emissions correlated well to active layer depth and $\mathrm{CH}_{4}$ concentration in soil pore water, especially in the Eriophorum-dominated community. Our results suggest that $\mathrm{CH}_{4}$ released from the thawed $\mathrm{CH}_{4}$ rich permafrost layer may be a key factor controlling $\mathrm{CH}_{4}$ emissions in boreal peatlands, and highlight that $\mathrm{CH}_{4}$ fluxes vary with vegetation type in boreal peatlands. With increas-
\end{abstract}

ing temperature in future climate patterns, increasing active layer depth and shifting plant functional groups in this region may have a significant effect on $\mathrm{CH}_{4}$ emission.

\section{Introduction}

Methane $\left(\mathrm{CH}_{4}\right)$, as one of the most important greenhouse gases, is 25 times more effective in absorbing heat in the atmosphere than carbon dioxide $\left(\mathrm{CO}_{2}\right)$ on a 100 -yr time horizon (IPCC, 2007). The atmospheric $\mathrm{CH}_{4}$ abundance increased from $715 \mathrm{ppb}$ in pre-industrial age to $1774 \mathrm{ppb}$ in 2005. Increases in atmospheric $\mathrm{CH}_{4}$ concentrations (148\%) are greater than the other two greenhouse gases $\left(\mathrm{CO}_{2} 35 \%\right.$ and $\mathrm{N}_{2} \mathrm{O} 18 \%$ ) over the same time period. In order to reduce uncertainties in future projections of Earth's climate change, the current global $\mathrm{CH}_{4}$ budget should be better known. Denman et al. (2007) estimated that more than $580 \mathrm{Tg} \mathrm{yr}^{-1}$ of $\mathrm{CH}_{4}$ are emitted to the atmosphere, with $33 \%$ originating from natural ecosystem sources. However, the contribution of different $\mathrm{CH}_{4}$ sources and sinks is still highly uncertain due to the sparseness of in situ observations.

Among all the natural ecosystem $\mathrm{CH}_{4}$ sources, natural wetlands are regarded as the single largest methane source, accounting for $20 \%$ of the global $\mathrm{CH}_{4}$ budget (Fung et al., 1987). While covering nearly $3 \%$ of Earth's land surface, northern peatlands store a carbon pool of $455 \mathrm{Pg}$ (Gorham, 1991), approximately accounting for one-third of the global soil carbon (Rydin and Jeglum, 2006), and could potentially release carbon in the form of $\mathrm{CH}_{4}$ to the atmosphere. The 
magnitude of $\mathrm{CH}_{4}$ emission from peatland ecosystems is a comprehensive result of several processes including $\mathrm{CH}_{4}$ production and oxidation in the peat profile and abiogenic mechanisms such as gas bubbles, diffusion, and gas transport through vascular plant aerenchyma (Whalen, 2005).

Previous studies demonstrated that wetland methane emissions depend on a large amount of abiotic and biotic factors, among the most important of which are temperature, water table depth, vegetation type, substrate quality and supply (Bellisario et al., 1999; Whalen, 2005). Temperature controls methanogenesis and $\mathrm{CH}_{4}$ oxidation by affecting methanogenic and methanotrophic bacteria. The wide range of $Q_{10}$ (reaction rate increase for a $10^{\circ} \mathrm{C}$ temperature increase) for methanogenesis and methane oxidation suggested a highly significant effect of temperature on $\mathrm{CH}_{4}$ production and oxidation rates (Whalen, 2005). Substrate availability and supply originating from wetland plant litter and/or root exudates determine $\mathrm{CH}_{4}$ production and oxidation. Otherwise, species composition of plants can affect $\mathrm{CH}_{4}$ emissions and substrate availability for methanogens. Previous evidence showed that the vascular plants such as Eriophorum species (Ström et al., 2011) and Carex species (Ding et al., 2005) have a very strong effect on $\mathrm{CH}_{4}$ emission in the northern wetlands, by supply of available substrate and/or gas transportation of aerenchyma. In addition, peatland soil aerobic (anaerobic) conditions resulting from a drop (increase) of the water table can influence $\mathrm{CH}_{4}$ oxidation (production) and then affect $\mathrm{CH}_{4}$ fluxes (Whalen, 2005).

Boreal regions are of close concern since they are expected to undergo large changes in temperature and precipitation (Turetsky et al., 2007). Large amounts of labile soil organic matter that is currently preserved by permafrost will be vulnerable to climate change and could result in changing $\mathrm{CH}_{4}$ emissions through changing peatland hydrology and thermal conditions. For example, permafrost degradation caused by warming will lower the water table following increased drainage in the discontinuous permafrost zone (Riordan et al., 2006) and increase thermokarst lake areas in the continuous permafrost zone (Smith et al., 2005). In addition, boreal peatland soil moisture varied in different permafrost zones owing to increasing difference between potential summer evapotranspiration and precipitation that has been reported (Klein et al., 2005). Under ongoing climate changes, the uncertainties of $\mathrm{CH}_{4}$ fluxes from boreal peatlands have increased, which might confuse the knowledge of the effects of climate change on the boreal peatland carbon cycle.

Many studies on peatland $\mathrm{CH}_{4}$ emissions have been conducted in Siberia (Nilsson et al., 2001; Bohn et al., 2007) and subarctic or arctic regions (Zona et al., 2009; JackowiczKorczyński et al., 2010). However, to our knowledge, there is no study reporting $\mathrm{CH}_{4}$ emissions from boreal peatland in the continuous permafrost zone in China. Understanding $\mathrm{CH}_{4}$ emission from peatland in the continuous permafrost zone can make us better understand $\mathrm{CH}_{4}$ emission patterns and increase the accuracy of estimating a peatland $\mathrm{CH}_{4}$ bud- get. The goal of this study was to provide a first dataset of $\mathrm{CH}_{4}$ fluxes from a permafrost peatland in Northeast China, and to investigate the factors controlling the seasonal $\mathrm{CH}_{4}$ fluxes from a permafrost peatland.

\section{Materials and methods}

\subsection{Study site and experiment installation}

The measurement was conducted in a minerotrophic peatland located in the north of Great Hing' an Mountains, Northeast China $\left(52.94^{\circ} \mathrm{N}, 122.86^{\circ} \mathrm{E}\right)$. The study site is situated in the continuous permafrost zone. The climate of this area is cool continental, with a 30-yr (1980-2009) mean annual temperature of $-3.9^{\circ} \mathrm{C}$ and mean annual precipitation of $452 \mathrm{~mm}, 203 \mathrm{~mm}$ of which falls in rainy season (July and August). The coldest monthly mean temperature is $-28.7{ }^{\circ} \mathrm{C}$ in January, and the warmest is $18.4^{\circ} \mathrm{C}$ in July. The surface of the peatland site is a mosaic of microforms, which are divided into hummock, tussock and hollow. Plants usually grow from early May to late September and the dominant evergreen shrubs are Chamaedaphne calyculata and Ledum palustre. Deciduous shrubs contain Vaccinium vitis-idaea and Betula fruticosa. Hummocks were covered by Sphagnum mosses (S. capillifolium, S. magellanicum), Polytrichum commune and previously mentioned shrubs. Tussocks support sedges (Eriophorum vaginatum) as the dominant vascular plant species, as well as sparse shrubs (Vaccinium vitisidaea, Ledum palustre). A scatter of bryophytes (Polytrichum juniperinum) were present in hollows. The soil type in our study site is classified as peat soil.

A set of twelve plots for gas sampling were selected, and eight of them were chosen so as to be representative of the dominant vegetation in the three microforms and to capture the variability for each of these situations. The intervals among these plots ranged from 5 to $20 \mathrm{~m}$. Four plots were established on the tussock and hollow places where the dominant plant species was Eriophorum vaginatum (Eriophorumdominated plots: EPs), and four plots on hummocks where dwarf shrubs and mosses were the dominant species (shrubmosses-dominated plots: SPs). In order to determine the influence of peatland vascular vegetation (Eriophorum vaginatum) on methane emission, four other plots were established on the bare peat where the above-ground parts of dominant vascular plants (Eriophorum vaginatum) were carefully cut and removed before each measurement (bare-peat plots: BPs). In order to make a comparison among these types, flux observations were conducted on the same date.

\subsection{Biomass determination and chemical analysis of soils}

Above-ground biomass (ABG) was measured by clipping three $1 \times 1 \mathrm{~m}$ quadrats for a shrub-mosses-dominated community and three $0.5 \times 0.5 \mathrm{~m}$ quadrats for a Eriophorum- 
dominated community in mid-August and sorting materials by species. We also collected mosses by clipping at the base of the capitulum following Moore et al. (2002). Plant tissues were oven-dried to a constant mass at $65^{\circ} \mathrm{C}$ and then were weighted.

To determine $\mathrm{pH}$, total carbon and nitrogen contents of soil from two varied-vegetation-dominated communities, three soil cores were collected from a depth of $0-20 \mathrm{~cm}$ on each community. Soil $\mathrm{pH}$ was determined by a glass electrode in a $1: 5$ soil: $10 \mathrm{mM} \mathrm{CaCl}_{2}$ solutions of fresh samples according to ISO 10390 standard. The soil samples used for carbon and nitrogen analysis were dried at room temperature and then milled and sieved using a $2 \mathrm{~mm}$ screen. Soil organic carbon and total nitrogen concentrations were analyzed by the Multi N/C 2100 Analyzer (containing an HT 1300 Solid Module, Analytik Jena AG, Germany) and the Kjeldahl digestion method using a Behr analyzer (Germany), respectively.

\subsection{Gas flux determination}

Gas fluxes were measured by the closed chamber and gas chromatography techniques (Wang and Wang, 2003; Song et al., 2009). The closed chamber was made by stainless steel and consisted of two parts: a square base collar (length: $50 \mathrm{~cm}$, width: $50 \mathrm{~cm}$ and height: $20 \mathrm{~cm}$ ) and a top chamber (length: $50 \mathrm{~cm}$, width: $50 \mathrm{~cm}$ and height: 50 or $70 \mathrm{~cm}$ ) opened at the bottom. The collar was inserted directly into the peat layer to a depth of $15 \mathrm{~cm}$, and kept in the soil during the entire observation period. The top chamber was put on the collar during gas sampling, and immediately removed after gas samples were collected. Two fans were fixed on the inside symmetrical corners of each chamber to keep the air mixed in the chamber closure during sampling. The chambers were wrapped with Styrofoam to prevent an increase in headspace air temperature due to heating when sampling. We built boardwalks to minimize disturbance on the plant and soil microenvironments around collars after the collars were installed.

Gas sampling started in June 2010 and continued until September 2011 at weekly interval during the two growing seasons. Gas samples were only collected in the morning (09:00-11:00 a.m.) because the flux during this period is almost equal to the daily mean flux (Tang et al., 2006). During the flux measurements, headspace samples $(50 \mathrm{ml}$ each) were drawn from the chamber every $10 \mathrm{~min}$ (including zero time) over half an hour period after enclosure using $60 \mathrm{ml}$ syringes and stored in Tedlar ${ }^{R}$ air sample bags $(100 \mathrm{ml}$, Delin Ltd, Liaoning, China), which had been pre-evacuated to close to $0 \mathrm{~Pa}$. A total of four samples were taken during a flux measurement.

The collected gas samples were delivered to Sanjiang Experimental Station of Wetland Ecology, Chinese Academy of Sciences, and analyzed within a week. Gas concentrations were measured by a modified gas chromatograph (Agilent
4890D, Agilent Co., Santa Clara, CA, USA). The gas chromatograph was equipped with a flame ionization detector (FID) for $\mathrm{CH}_{4}$ analysis. The air bags with known standard concentration of $\mathrm{CH}_{4}$ were delivered with the collected samples to the laboratory to evaluate the leakage of trace gases during transport and analysis. No significant changes in the concentration of the standards were found during one week of transfer. The fluxes were calculated as the change in chamber concentration over time. The fluxes were rejected unless they yielded a linear regression with coefficient $R^{2}>0.8$ for $\mathrm{CH}_{4}$. More details of the flux calculation can be found in Song et al. (2009).

\subsection{Dissolved methane concentration}

Soil pore water was sampled at several depths to determine dissolved $\mathrm{CH}_{4}$ concentration if there was enough pore water for extracting. A set of stainless-steel tubes varied in length were installed before measuring at $10 \mathrm{~cm}$ intervals from peatland surface to $40 \mathrm{~cm}$ below the surface. Immediately after gas flux measurements, pore water samples $(20 \mathrm{ml})$ were drawn from tubes using a syringe and then injected into evacuated vials $(60 \mathrm{ml})$. Prior to determining $\mathrm{CH}_{4}$ concentration in pore water, vials were shaken for a few minutes to extract dissolved $\mathrm{CH}_{4}$. Subsequently, $40 \mathrm{ml}$ of the headspace was sampled by a syringe and stored in a Tedlar ${ }^{R}$ air sample bag. $\mathrm{CH}_{4}$ concentration was analyzed as described above. The methods for calculating dissolved pore water $\mathrm{CH}_{4}\left(\mu \mathrm{mol} \mathrm{l}^{-1}\right)$ have been described by Ding et al. (2003).

\subsection{Abiotic variables}

Air temperature, soil temperature, depth of active layer and groundwater level were measured at the same time as gas sampling. Air temperature inside the chambers was measured with a thermometer inserted into the chambers, and soil temperature was measured $0,5,10,15$ and $20 \mathrm{~cm}$ below the peat surface next to the chambers using a portable digital thermometer (JM 624, Jinming Instrument CO., Ltd, Tianjin, China). Active layer depth was simultaneously measured by a steel rod. Groundwater level was monitored by digging a small well adjacent to the collar over the frost-free season. Daily precipitation data were manually recorded near the sampling site.

\subsection{Data analysis}

Correlation analysis (Spearman's rank correlation test) was used for identifying the relationships between $\mathrm{CH}_{4}$ fluxes and environmental factors (i.e. temperature, water table depth, active layer depth and soil pore water $\mathrm{CH}_{4}$ concentration). In all analyses where $p<0.05$, the factor tested and the relationships were considered statistically significant. The one-way analysis of variance (ANOVA) was conducted to test the differences in soil chemical characters for both communities. All the statistical analyses were conducted 
Table 1. Above-ground biomass and the main chemical characteristics of the soils $(0-20 \mathrm{~cm}$ depth) from the shrub-moss-dominated community and Eriophorum-dominated community. Values represent the mean and the standard deviation $(n=3)$.

\begin{tabular}{|c|c|c|c|c|c|c|c|}
\hline \multirow{2}{*}{ Community } & \multicolumn{4}{|c|}{ Above-ground biomass* $\left(\mathrm{g} \mathrm{DW} \mathrm{m}^{-2}\right)$} & \multirow{2}{*}{$\operatorname{SOC}\left(\mathrm{g} \mathrm{kg}^{-1}\right)$} & \multirow{2}{*}{$\mathrm{TN}\left(\mathrm{g} \mathrm{kg}^{-1}\right)$} & \multirow{2}{*}{$\mathrm{pH}$} \\
\hline & Shrubs & Sedges & Mosses & Total & & & \\
\hline Shrub-mosses-dominated & $424.1 \pm 35.1$ & $15.7 \pm 8.2$ & $342.7 \pm 55.4$ & $782.5 \pm 97.7$ & $424.7 \pm 40.5$ & $17.2 \pm 2.1$ & $5.0 \pm 0.4$ \\
\hline Eriophorum-dominated & $104.1 \pm 0.8$ & $79.2 \pm 25.3$ & $119.5 \pm 28.7$ & $302.8 \pm 30.1$ & $403.7 \pm 20.6$ & $19.1 \pm 1.5$ & $4.7 \pm 0.1$ \\
\hline
\end{tabular}

* Above-ground biomass was measured in mid-August when plants reached their maximum biomass.

by Software packages SPSS 13.0 (SPSS Inc., Chicago, IL, USA) and figures were prepared by Origin 8.0 (Origin Lab Corporation, USA) for Windows XP.

\section{Results and discussion}

\subsection{Environment variables, biomass, soil chemical characteristics, $\mathrm{CH}_{4}$ concentration in pore water and $\mathrm{CH}_{4}$ fluxes}

During the sampling period, monthly mean air temperature (MMAT) varied from $5.3^{\circ} \mathrm{C}$ (September 2011) to $20.3^{\circ} \mathrm{C}$ (July 2011; Fig. 1a). There was no marked discrepancy between the MMAT and the 30-yr mean value in the two measurement years. However, we observed extreme daily temperatures in the last few days of June, and the maximum daily temperature reached $39.4^{\circ} \mathrm{C}$ on 27 June 2010 . Accumulative precipitations from May to September were 325.9 and $493.7 \mathrm{~mm}$ in 2010 and 2011, which were $11 \%$ lower and $34.8 \%$ greater than the 30 -yr mean value during the same period, respectively (Fig. 1b). A heavy rain occurred on $23 \mathrm{Au}-$ gust 2011 and the accumulative rainfall was $129.1 \mathrm{~mm}$ (data not shown). The seasonality of ground temperature and soil temperature were consistent with the seasonal patterns of air temperature during the sampling period in 2011. The inchamber soil temperatures observed in different vegetation plots showed that soil temperatures at the SP site were a little higher than that at the EP site (Fig. 2). The presence of Sphagnum at the SP site preserved soil heat diffusion. The water table depth throughout the measurement period ranged from -10.7 to $-24 \mathrm{~cm}$ (minus value means below the surface) at the SP site and from -10.5 to $-36 \mathrm{~cm}$ at the EP site (Fig. 3). The water table depth was consistently higher at the SP site than at the EP site during the two growing seasons (Fig. 3), and the average difference in water table between the two sites was $4 \mathrm{~cm}$. A similar seasonal variation of water table depth at the SP and EP sites was observed, and the lowest value occurred in late June or early July due to higher temperature and less precipitation.

At the beginning of the measurement, peatland surface soil was frozen. The active layer depth continuously increased with air and soil temperatures at the initial stage. In the late sampling period, the active layer depth still increased with

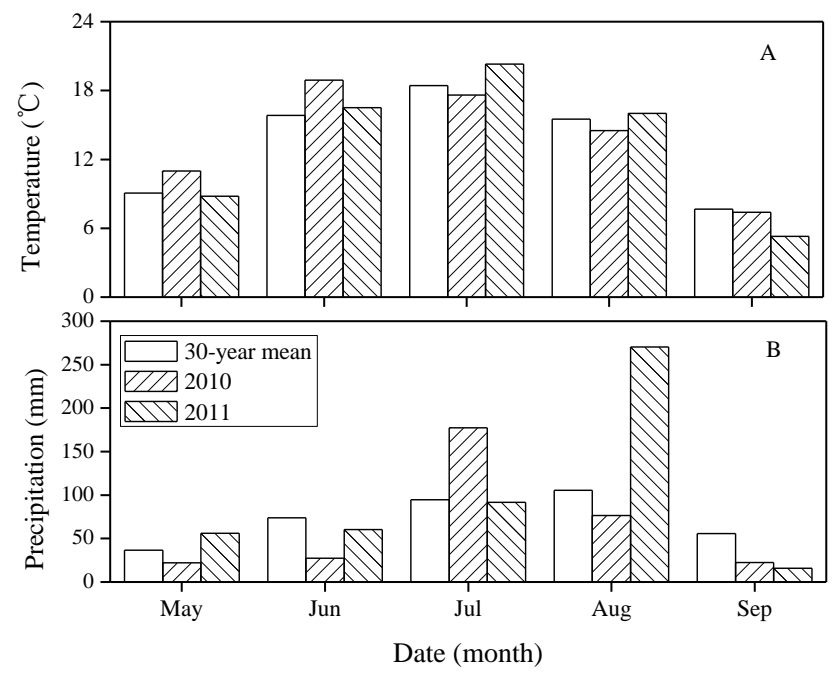

Fig. 1. Climatic characteristics of the study site during the growing season in 2010 and 2011 on the background of the long-term normal period (1980-2009) recorded by China Meteorological Administration. (A) Monthly average temperature; (B) monthly accumulative precipitation.

decreasing air and soil temperatures. This might be on account of heat in deep soil transferring slower than that in upper soil layers and the atmosphere. The maximum active layer depth reached $72.4 \mathrm{~cm}$ and $80.7 \mathrm{~cm}$ by the end of the observation period in 2010 and 2011, respectively.

The above-ground biomass of shrubs, sedges and mosses from both communities in the peatland is given in Table 1. The total ABG from the SP site was two times higher than that from the EP site, whereas the ABG of sedges was much lower at the SP site. There was no significant difference in soil chemical characteristics between the SP and EP sites ( $p=0.260$ for SOC and 0.236 for TN; Table 1). Soil organic carbon content was a little higher at the SP site $\left(424.7 \pm 40.5 \mathrm{~g} \mathrm{~kg}^{-1}\right)$ than at the EP site $\left(403.7 \pm 20.6 \mathrm{~g} \mathrm{~kg}^{-1}\right)$. The inverse pattern was observed in the total nitrogen content. $\mathrm{pH}$ was slightly lower at the EP site compared to the SP site.

The details and seasonal fluctuations in pore water concentration of $\mathrm{CH}_{4}$ measured in the peatland soil profile can be seen in Fig. 4. Pore water $\mathrm{CH}_{4}$ concentration at $20 \mathrm{~cm}$ below 


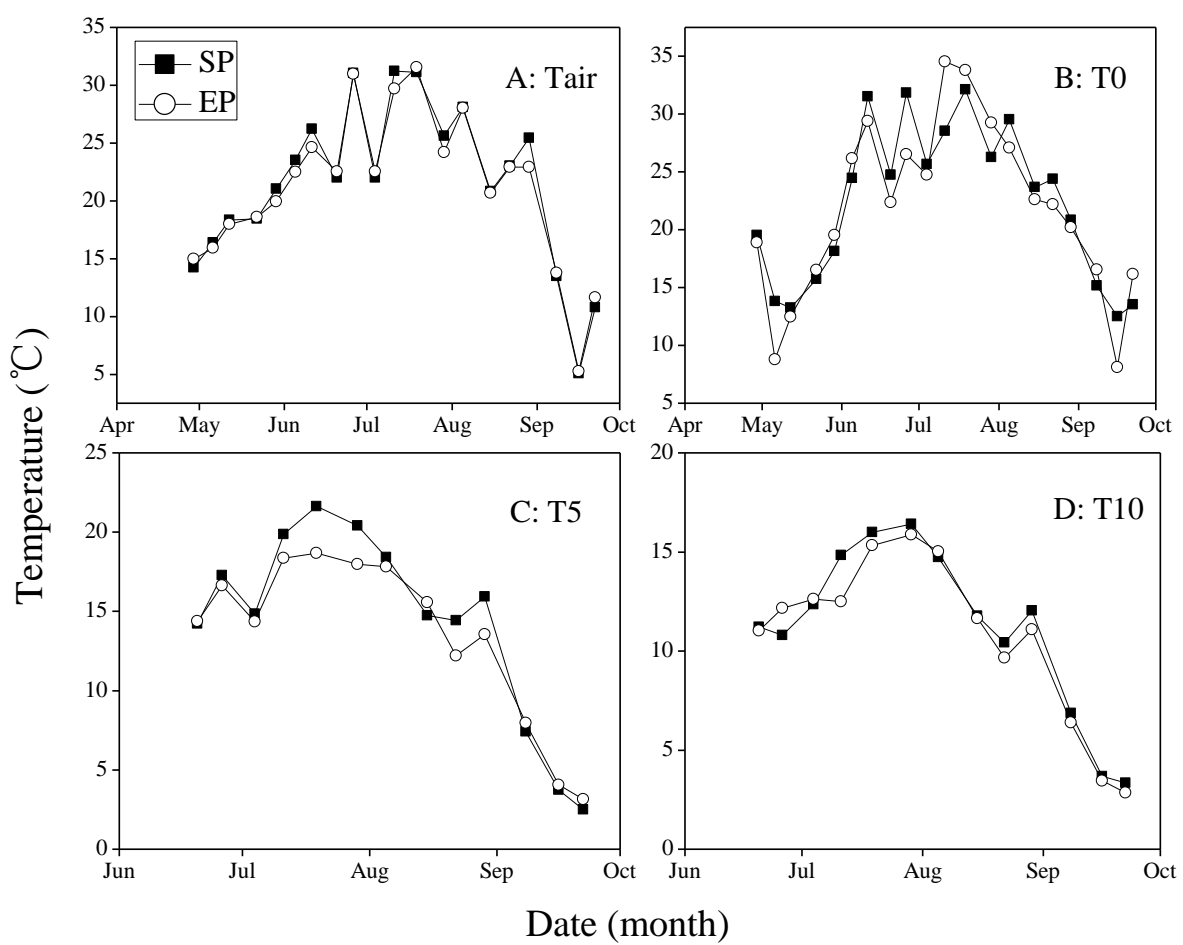

Fig. 2. Temperatures recorded by digital thermometer at SP (shrub-mosses plot) and EP (Eriophorum plot) sites during sampling in 2011. (A) Air temperature inside the chamber; (B) peat surface temperature; (C) soil temperature at $5 \mathrm{~cm}$ depth; (D) soil temperature at $10 \mathrm{~cm}$ depth.

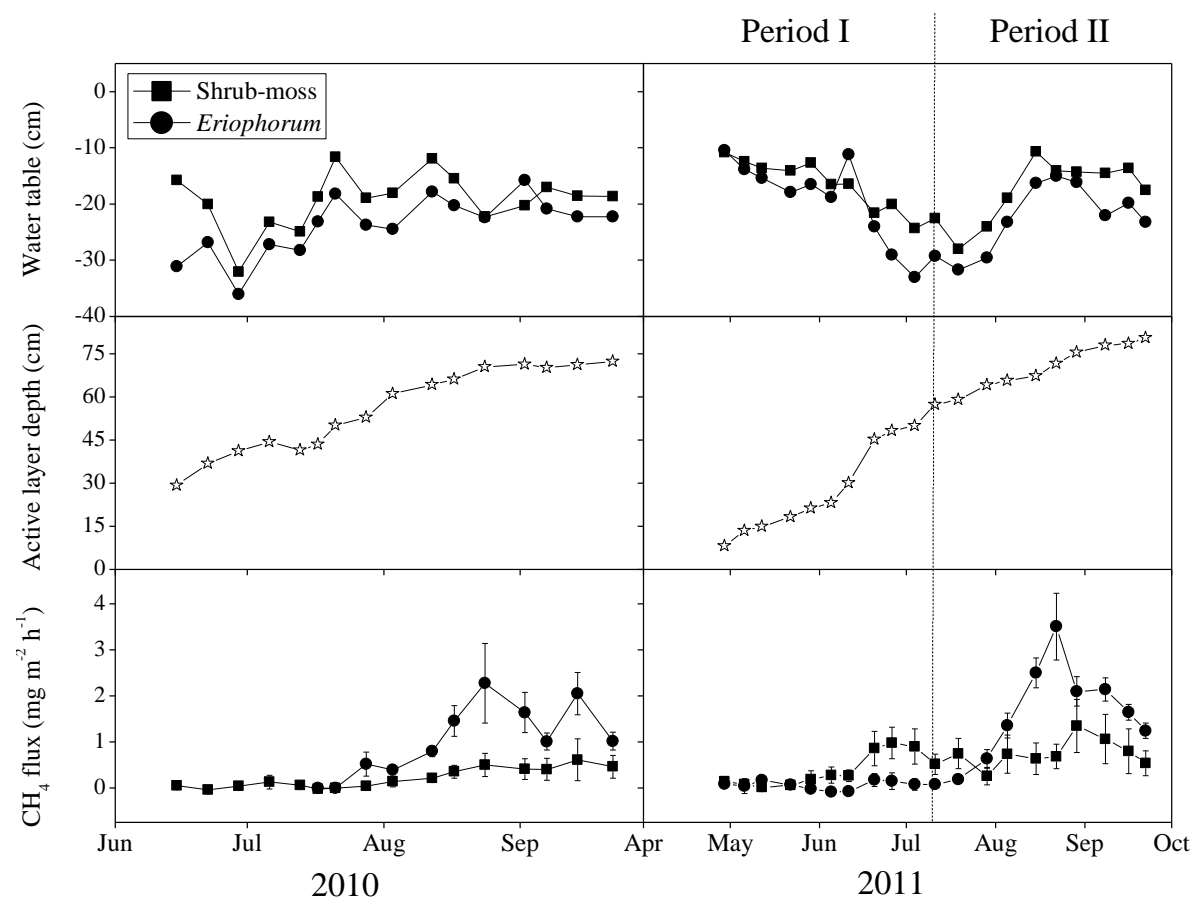

Date (month)

Fig. 3. The seasonal variation of net $\mathrm{CH}_{4}$ fluxes and environmental variables (water table and active layer depth) observed at the study site during the growing seasons of 2010 and 2011. 


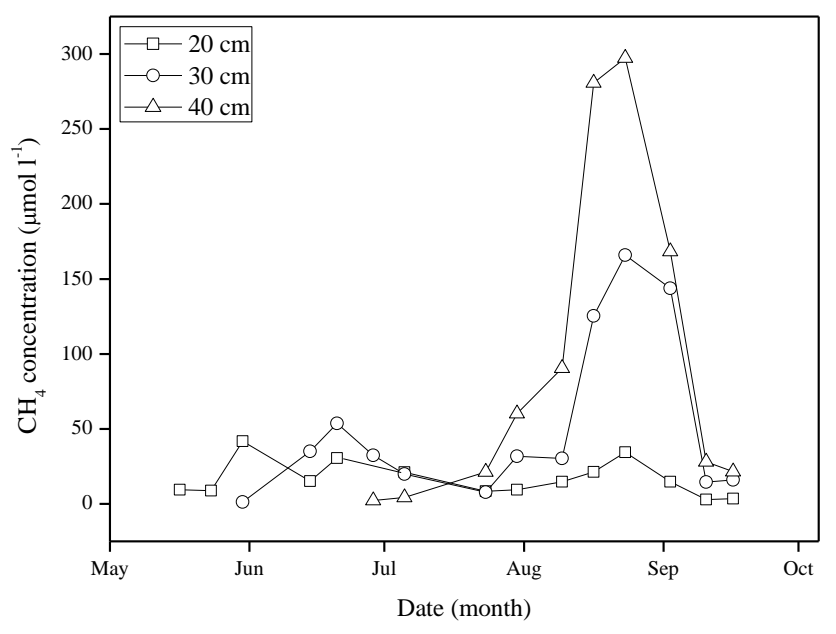

Fig. 4. Seasonal variation of dissolved pore water $\mathrm{CH}_{4}$ concentrations at different soil depths was determined for the study site during sampling in 2011.

the peatland surface showed no seasonal variation and the mean $\mathrm{CH}_{4}$ concentration in pore water was $14.37 \mu \mathrm{mol} 1^{-1}$. However, a significant seasonal variation of $\mathrm{CH}_{4}$ concentration in 30 and $40 \mathrm{~cm}$ below peat surface was observed. $\mathrm{CH}_{4}$ concentrations at 30 and $40 \mathrm{~cm}$ depths increased following the development of the growing season. Correlation analysis showed that average $\mathrm{CH}_{4}$ concentration between $20 \mathrm{~cm}$ and $40 \mathrm{~cm}$ was related to soil temperature at $40 \mathrm{~cm}$ depth $(r=0.573, p=0.05)$. Figure 4 also shows that pore water $\mathrm{CH}_{4}$ concentrations increased with depth. At the depth from $20 \mathrm{~cm}$ to $40 \mathrm{~cm}$, the concentration of $\mathrm{CH}_{4}$ increased sharply by 2 to 10 times magnitude.

Generally, the peatland emitted $\mathrm{CH}_{4}$ to the atmosphere during the two growing seasons, although $\mathrm{CH}_{4}$ absorption might occur occasionally. At the SP site, $\mathrm{CH}_{4}$ fluxes were in the range of -0.02 to $0.51 \mathrm{mg} \mathrm{m}^{-2} \mathrm{~h}^{-1}$, with a mean value of $0.21 \mathrm{mg} \mathrm{m}^{-2} \mathrm{~h}^{-1}$ in the measuring period from June to September in 2010. In 2011, $\mathrm{CH}_{4}$ fluxes ranged from 0.02 to $1.35 \mathrm{mg} \mathrm{m}^{-2} \mathrm{~h}^{-1}$ during the entire growing season at the SP site, and the mean seasonal flux was $0.56 \mathrm{mg} \mathrm{m}^{-2} \mathrm{~h}^{-1}$. $\mathrm{CH}_{4}$ fluxes measured from the EP site were significantly higher than that from the SP site, which ranged from -0.01 to $2.28 \mathrm{mg} \mathrm{m}^{-2} \mathrm{~h}^{-1}$ with a mean flux of $1.02 \mathrm{mg} \mathrm{m}^{-2} \mathrm{~h}^{-1}$ in 2010 and -0.08 to $3.51 \mathrm{mg} \mathrm{m}^{-2} \mathrm{~h}^{-1}$ with a mean flux of $0.80 \mathrm{mg} \mathrm{m}^{-2} \mathrm{~h}^{-1}$ in 2011. In the present study, $\mathrm{CH}_{4}$ fluxes obtained through static chambers during the growing seasons $\left(\sim-0.08-3.51 \mathrm{mg} \mathrm{m}^{-2} \mathrm{~h}^{-1}\right)$ are greatly higher than that from Alaskan upland tundra (Bartlett et al., 1992), and they are similar in range to those from boreal raised bog (Pelletier et al., 2007) and subarctic/arctic fen (Christensen, 1993). The $\mathrm{CH}_{4}$ emissions are much lower than those from the BOREAS peatlands (Bubier et al., 1995) and Xiaoxing' an Mountain peatlands (Sun et al., 2011).
Figure 3 shows that the seasonal variations of $\mathrm{CH}_{4}$ flux exist for both sites. A similar seasonal trend of $\mathrm{CH}_{4}$ fluxes in disparate observation years was found at the SP and EP sites. However, the variation in $\mathrm{CH}_{4}$ emissions at the SP site is lower than that at the EP site. Except for the vascular plants regulating methane emissions, methane oxidation in in situ conditions may play a more important role in hummocks than in tussocks. $\mathrm{CH}_{4}$ emissions gradually increased with the development of growing season and peaked in late August in both years. Unlike other previous studies that reported no seasonal variation of $\mathrm{CH}_{4}$ fluxes from peatlands, we found a distinct temporal variation in methane emissions where $\mathrm{CH}_{4}$ fluxes peaked in late summer when the active layer reached the gas-contained layer, and which was consistent with peak pore water $\mathrm{CH}_{4}$ concentration. Our results were consistent with Moore and Knowles (1990), who found $\mathrm{CH}_{4}$ fluxes peaked in the later growing season from a subarctic fen in Quebec.

\subsection{Controls on $\mathrm{CH}_{4}$ flux}

Previous studies have shown that temperature (Bellisario et al., 1999; Pelletier et al., 2007; Sun et al., 2011) and water table depth (Moore et al., 2011) were primary factors that controlled peatland $\mathrm{CH}_{4}$ emissions. The relationships between $\mathrm{CH}_{4}$ fluxes and environmental factors such as temperature, water table depth and active layer depth in an independent observation year were examined. The site-specific $\mathrm{CH}_{4}$ fluxes did not show any relationship with soil or air temperature and water table depth, indicating a complicated conjunct effect of variables on $\mathrm{CH}_{4}$ flux. It was consistent with Christensen et al. (1995), who found no correlations between environmental factors and $\mathrm{CH}_{4}$ emission in Siberian mesic tundra. Ström et al. (2011) also found no correlations between seasonal mean $\mathrm{CH}_{4}$ fluxes and water table depth and soil temperature in an arctic wetland. In the present study, the controls on seasonal variation of $\mathrm{CH}_{4}$ flux were distinct at different stages of plant growth. In the early growing season (Period I), when moisture was adequate to support methanogenesis, temperature played a critical role in peatland $\mathrm{CH}_{4}$ emission (Table 2). However, there was a lag time between rising temperatures and $\mathrm{CH}_{4}$ flux in the early season because microbial communities and vegetation required time to become established. The following mechanisms might interpret temperature-dependence $\mathrm{CH}_{4}$ fluxes during the early growing season. Firstly, temperature was an important control on methanogenesis. The widely reported $Q_{10}$ values for methanogenesis ranging from 1 to 35 in boreal peatland soils (Whalen, 2005) suggested that temperature sensitivity of the underlying microbial processes involved in the production of $\mathrm{CH}_{4}$ was high under appropriate substrate and moisture conditions. The lack of $\mathrm{CH}_{4}$ production capacity under low temperature magnified the effect of temperature on $\mathrm{CH}_{4}$ emission. Secondly, temperature controlled plant growth, which could provide not only substrate for methanogenesis but also 
Table 2. Correlation coefficients between mean $\mathrm{CH}_{4}$ fluxes and abiotic factors during the sampling period of 2011.

\begin{tabular}{|c|c|c|c|c|c|c|c|c|}
\hline & \multicolumn{3}{|c|}{ Temperature ${ }^{\mathrm{a}}\left({ }^{\circ} \mathrm{C}\right)$} & \multicolumn{3}{|c|}{ Water table depth $(\mathrm{cm})$} & \multirow{2}{*}{$\begin{array}{c}\text { Active layer depth }(\mathrm{cm}) \\
\text { Entire }\end{array}$} & \multirow{2}{*}{$\begin{array}{c}\begin{array}{c}\text { Pore water } \mathrm{CH}_{4} \\
\text { concentration } \\
\left(\mu \mathrm{mol} 1^{-1}\right)\end{array} \\
\text { Entire }\end{array}$} \\
\hline & Period I & Period II & Entire & Period I & Period II & Entire & & \\
\hline $\begin{array}{l}\text { Mean } \mathrm{CH}_{4} \text { flux } \\
\left(\mathrm{mg} \mathrm{m}^{-2} \mathrm{~h}^{-1}\right)\end{array}$ & $0.721^{*}$ & -40.491 & 0.033 & -0.539 & $0.842^{* *}$ & -0.192 & $0.865^{* *}$ & $0.759^{* *}$ \\
\hline $\begin{array}{l}\text { Pore water } \mathrm{CH}_{4} \\
\text { concentration }\left(\mu \mathrm{moll}^{-1}\right)\end{array}$ & & & 0.139 & & & $0.607^{*}$ & $0.512^{*}$ & 1 \\
\hline
\end{tabular}

* Correlation is significant at 0.05 levels; ${ }^{* *}$ correlation is significant at 0.01 levels. Period I and II were arbitrarily defined at before and after 8 July 2011 .

a Average temperature between 5 and $10 \mathrm{~cm}$ below peatland surface.

an efficient pathway for methane to liberate from peat to the atmosphere (Joabsson et al., 1999). In addition, as temperature increased, thaw depth of permafrost gradually increased, which can create appropriate soil circumstances such as saturation status and re-release of substrate previously preserved in the frozen layer for methanogens and methanogenesis (Yavitt et al., 2006). Therefore, the magnitude of $\mathrm{CH}_{4}$ dependent on soil temperature was the important limiting factor for the $\mathrm{CH}_{4}$ emission rate in the early growing season. The weak statistical relationship between methane emission and temperature at the peatland site during the growing season probably reflected the high spatial variability in emission rates at the plots, fluctuations in water table position, and seasonal changes in vegetation cover.

In general, water table position acted as a creation of aerobic and anaerobic conditions in the peat soil profile, which determined peatland $\mathrm{CH}_{4}$ emissions. Studies have revealed that $\mathrm{CH}_{4}$ fluxes increased from soils under elevated water tables, or high soil moisture contents (Moore and Knowles, 1989). In this study, soil moisture was large due to low evapotranspiration in the early growing season, but $\mathrm{CH}_{4}$ fluxes were very low. A possible reason was that $\mathrm{CH}_{4}$ production in anaerobic conditions was constrained by low soil temperature and limited substrate supply, and part of $\mathrm{CH}_{4}$ might be consumed in the aerobic layer during the process of transmission to the atmosphere. As the growing season developed (Period II), the positive correlation between $\mathrm{CH}_{4}$ emission and water table depth was shown (Table 2). This suggests that the effects of water table depth on methane emission will be enhanced under appropriate temperature conditions. It was consistent with other studies that found similar relationships, conducted in boreal peatlands (Roulet et al., 1993). A higher water table depth caused by summer precipitation and permafrost thaw might result in a larger anoxic $\mathrm{CH}_{4}$ production zone and stimulate emissions.

This study was performed in the mountain peatland located in the southern margin of the Eurasian permafrost zone where the active layer depth has been increasing in recent decades (Jin et al., 2000). Some previous studies have shown that $\mathrm{CH}_{4}$ flux correlated well with active layer depth in peatlands underlain by permafrost (van Huissteden et al., 2005).
In our study, we found a positive correlation between thaw depth and the gas fluxes of $\mathrm{CH}_{4}$ (Table 2), which was consistent with the above mentioned studies. However, Wille et al. (2008) reported that $\mathrm{CH}_{4}$ flux did not correlate with the thaw depth in arctic tundra. The reasons they drew were that the majority of $\mathrm{CH}_{4}$ originated from the upper soil layers, and the contribution of deep soil layers to methane emissions was small due to the temperature gradient in the thawed active layers and temperature dependence of microbial activity. However, recent studies reported that layers nearest the top of the permafrost $(50-100 \mathrm{~cm})$ in Alaska and Siberia contained higher $\mathrm{CH}_{4}$ concentrations, which suggest that the majority of $\mathrm{CH}_{4}$ will release from the eroding permafrost (Michaelson et al., 2011). Song et al. (2012) observed high $\mathrm{CH}_{4}$ concentration in the refrozen active layer and upper permafrost layer in our study region, which could partly explain high $\mathrm{CH}_{4}$ flux in the late growing season when the active layer reached tens of centimeters. The high $\mathrm{CH}_{4}$ content in the permafrost might be originated from modern methanogenesis by coldadapted methanogenic archaea in permafrost soil (Wagner et al., 2007) and release of trapped $\mathrm{CH}_{4}$ formed in the unfrozen active layer during previous winter. It is also possible that $\mathrm{CH}_{4}$ production took place in the freshly thawed permafrost due to the recovery of the bacteria from the upper permafrost (Coolen et al., 2011). In our study, we observed decreasing $\mathrm{CH}_{4}$ flux with increasing thaw depth during the late growing season. This can be explained by decreasing air and surface soil temperatures constraining $\mathrm{CH}_{4}$ production and little root survival in deeper soil layers, which limits $\mathrm{CH}_{4}$ transport and emission.

The magnitude of $\mathrm{CH}_{4}$ concentration in soil pore water increasing with depth indicated that $\mathrm{CH}_{4}$ production was high in the deep saturated soil layer. The seasonal variation in $\mathrm{CH}_{4}$ emission was significantly correlated with mean soil pore water $\mathrm{CH}_{4}$ (Table 2). It implied that the magnitude of soil pore water $\mathrm{CH}_{4}$ controlled $\mathrm{CH}_{4}$ emission rates in the peatland. Our results are in agreement with Nouchi and Mariko (1993), who reported that $\mathrm{CH}_{4}$ emission rate was proportional to pore water $\mathrm{CH}_{4}$ concentration. Soil pore water containing high $\mathrm{CH}_{4}$ concentrations was in correspondence with the EP site $\mathrm{CH}_{4}$ flux rates recorded in late growing season. 


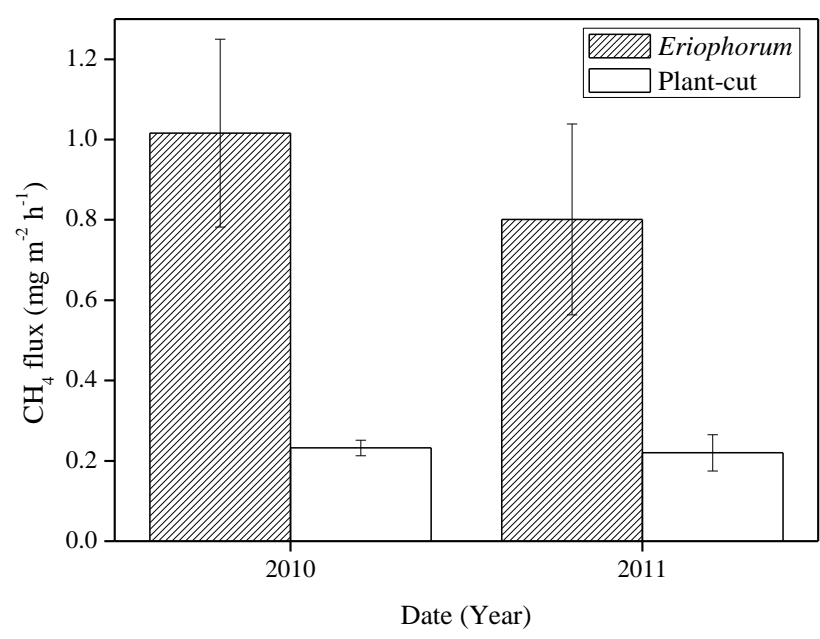

Fig. 5. Seasonal mean $\mathrm{CH}_{4}$ flux from the EP and BP sites for both years.

This suggests that plants at the EP site are more effective at transporting $\mathrm{CH}_{4}$.

We found that $\mathrm{CH}_{4}$ emission from the EP site was significantly higher than that from the SP site (Fig. 3). This can be partly explained by the presence of sedges (Eriophorum vaginatum) between the two sites. At the EP site, the dominant plant was Eriophorum vaginatum, classified as a vascular plant, while the SP site was dominantly covered by Sphagnum species, dwarf shrubs, and sparse Eriophorum vaginatum. We observed that the above-ground biomass of Eriophorum vaginatum from the SP site was much lower than that from the EP site (Table 1). The vascular plants of peatland could play an important role in gas exchange between the land and the atmosphere (Joabsson et al., 1999). In addition, $\mathrm{CH}_{4}$ transport through Eriophorum was the major pathway for $\mathrm{CH}_{4}$ fluxes (Frenzel and Rudolph, 1998). We also found that methane fluxes would decrease $77 \%$ and $73 \%$ from the EP site in 2010 and 2011 after cutting the above-ground part of Eriophorum vaginatum (Fig. 5). However, vascular plants might act as conduit for transferring oxygen to the rhizosphere, which both inhibits archaeal $\mathrm{CH}_{4}$ production and enhances methanotrophy. Yet, Frenzel and Rudolph (1998) found that oxidation of $\mathrm{CH}_{4}$ was negligible during its passage through $E$. angustifolium. In addition, root exudates and fine root litter of Eriophorum could stimulate $\mathrm{CH}_{4}$ production. Ström et al. (2011) reported that Eriophorum secreted more organic acids than other highly bio-available organic matters that could be easily utilized by methanogens in arctic wetland. Mosses contributed less significantly to active gas transport since they did not develop real root systems in peat (Sheppard et al., 2007). Otherwise, $\mathrm{CH}_{4}$ oxidation was reported from mosses originating from high-latitude wetlands, which decreased $\mathrm{CH}_{4}$ emissions from anoxic conditions (Larmola et al., 2010). So, different com- positions of vegetation in peatland can explain the spatial variation of $\mathrm{CH}_{4}$ fluxes.

\section{Conclusions}

Seasonal methane fluxes were measured from a boreal peatland ecosystem in a continuous permafrost zone for two consecutive years. Seasonal average $\mathrm{CH}_{4}$ fluxes ranged from 0.21 to $1.02 \mathrm{mg} \mathrm{m}^{-2} \mathrm{~h}^{-1}$, with an apparent seasonal variation. Our results showed that environmental factors such as temperature and water table level were not responsible for regulating temporal variations of methane emission. $\mathrm{CH}_{4}$ emission rates during the growing season were strongly controlled by plant, active layer depth and $\mathrm{CH}_{4}$ concentrations in soil pore water. It implies that permafrost peatland under warming conditions can create a positive feedback to climate change due to increased $\mathrm{CH}_{4}$ emission through altering plant composition and increasing active layer depth.

As $\mathrm{CH}_{4}$ emission from ecosystems depended on the balance of $\mathrm{CH}_{4}$ production and oxidation, the determination of the seasonal potential $\mathrm{CH}_{4}$ productions and oxidations in soil layers might provide some evidence for explanation of the seasonal and spatial variations of $\mathrm{CH}_{4}$ fluxes from boreal peatland ecosystems. In addition, future studies should focus on exploring the origination of plenty of $\mathrm{CH}_{4}$ in lower permafrost layers and soil pore water at tens of centimeters depth in peatland, which might promote our understanding of methane emission from peatlands in permafrost zones.

Acknowledgements. This work was funded by National Natural Science Foundation of China (No. 41125001, No. 40930527, No. 41001051), Strategic Priority Research Program - Climate Change: Carbon Budget and Related Issue of the Chinese Academy of Sciences (No. XDA05050508, No. XDA05020502), National Basic Research Program (973) of China (No. 2009CB421103), and the Key Project of CAS (No. KZCX2-YW-JC301). We thank two reviewers for their thoughtful comments, which helped in improving the manuscript. Authors thank Guisheng Yang, Yanyu Song, Xiaoxin Sun and Jiaoyue Wang for enthusiastic laboratory assistance. We also would like to thank Yue Sun for her work at the field site.

Edited by: X. Wang 


\section{References}

Bartlett, K. B., Crill, P. M., Sass, R. L., Harriss, R. C., and Dise, N. B.: Methane Emissions from Tundra Environments in the YukonKuskokwim Delta, Alaska, J. Geophys. Res.-Atmos., 97, 1664516660, 1992.

Bellisario, L. M., Bubier, J. L., Moore, T. R., and Chanton, J. P.: Controls on $\mathrm{CH}_{4}$ emissions from a northern peatland, Global Biogeochem. Cy., 13, 81-91, 1999.

Bohn, T. J., Lettenmaier, D. P., Sathulur, K., Bowling, L. C., Podest, E., McDonald, K. C., and Friborg, T.: Methane emissions from western Siberian wetlands: heterogeneity and sensitivity to climate change, Environ. Res. Lett., 2, 045015, doi:10.1088/17489326/2/4/045015, 2007.

Bubier, J. L., Moore, T. R., Bellisario, L., Comer, N. T., and Crill, P. M.: Ecological controls on methane emissions from a northern peatland complex in the zone of discontinuous permafrost, manitoba, Canada, Global Biogeochem. Cy., 9, 455-470, 1995.

Christensen, T. R.: Methane emission from arctic tundra, Biogeochemistry, 21, 117-139, 1993.

Christensen, T. R., Jonasson, S., Callaghan, T. V., and Havstrom, M.: Spatial variation in high-latitude methane flux along a transect across Siberian and European tundra environments, J. Geophys. Res.-Atmos., 100, 21035-21045, 1995.

Coolen, M. J. L., van de Giessen, J., Zhu, E.Y., and Wuchter, C.: Bioavailability of soil organic matter and microbial community dynamics upon permafrost thaw, Environ. Microbiol., 13, 22992314, 2011

Denman, K. L., Brasseur, G., Chidthaisong, A., Ciais, P., Cox, P. M., Dickinson, R. E., Hauglustaine, D., Heinze, C., Holland, E., Jacob, D., Lohmann, U., Ramachandran, S., da Silva Dias, P. L., Wofsy S. C., and Zhang, X.: Couplings Between Changes in the Climate System and Biogeochemistry, in: Climate Change 2007: The Physical Science Basis. Contribution of Working Group I to the Fourth Assessment Report of the Intergovernmental Panel on Climate Change, edited by: Solomon, S., Qin, D., Manning, M., Chen, Z., Marquis, M., Averyt, K. B., Tignor, M., and Miller H. L., Cambridge University Press, Cambridge, United Kingdom and New York, NY, 499-587, 2007.

Ding, W. X., Cai, Z. C., Tsuruta, H., and Li, X. P.: Key factors affecting spatial variation of methane emissions from freshwater marshes, Chemosphere, 51, 167-173, 2003.

Ding, W., Cai, Z., and Tsuruta, H.: Plant species effects on methane emissions from freshwater marshes, Atmos. Environ., 39, 3199 3207, 2005

Frenzel, P. and Rudolph, J.: Methane emission from a wetland plant: the role of $\mathrm{CH}_{4}$ oxidation in Eriophorum, Plant Soil, 202, 27-32, 1998.

Fung, I., Matthews, E., and Lerner, J.: Atmospheric Methane Response to Biogenic Sources - Results from a 3-D Atmospheric Tracer Model, Abstr. Pap. Am. Chem. S., 193, 6-Geoc, 1987.

Gorham, E.: Northern Peatlands: Role in the Carbon Cycle and Probable Responses to Climatic Warming, Ecol. Appl., 1, 182195, 1991.

IPCC: Solomon, S., Qin, D., Manning, M., Chen, Z., Marquis, M., Averyt, K. B., Tignor M., and Miller, H. L. (Eds.), Climate Change 2007: The Physical Science Basis, Contribution of Working Group I to the Fourth Assessment Report of the Intergovernmental Panel on Climate Change. Cambridge University Press, Cambridge, United Kingdom and New York, NY, USA,
996 pp., 2007.

Jackowicz-Korczyński, M., Christensen, T. R., Bäckstrand, K., Crill, P., Friborg, T., Mastepanov, M., and Ström, L.: Annual cycle of methane emission from a subarctic peatland, J. Geophys. Res., 115, G02009, doi:10.1029/2008JG000913, 2010.

Jin, H. J., Li, S. X., Cheng, G. D., Wang, S. L., and Li, $\mathrm{X}$.: Permafrost and climatic change in China, Global Planet. Change, 26, 387-404, 2000.

Joabsson, A., Christensen, T. R., and Wallen, B.: Vascular plant controls on methane emissions from northern peatforming wetlands, Trends Ecol. Evol., 14, 385-388, 1999.

Klein, E., Berg, E. E., and Dial, R.: Wetland drying and succession across the Kenai Peninsula Lowlands, south-central Alaska, Can. J. Forest. Res., 35, 1931-1941, 2005.

Larmola, T., Tuittila, E. S., Tiirola, M., Nykanen, H., Martikainen, P. J., Yrjala, K., Tuomivirta, T., and Fritze, H.: The role of Sphagnum mosses in the methane cycling of a boreal mire, Ecology, 91, 2356-2365, 2010.

Michaelson, G. J., Ping, C. L., and Jorgenson, M. T.: Methane and carbon dioxide content in eroding permafrost soils along the Beaufort Sea coast, Alaska, J. Geophys. Res., 116, G01022, doi:10.1029/2010JG001387, 2011.

Moore, T. R. and Knowles, R.: The Influence of Water-Table Levels on Methane and Carbon-Dioxide Emissions from Peatland Soils, Can. J. Soil. Sci., 69, 33-38, 1989.

Moore, T. R. and Knowles, R.: Methane Emissions from Fen, Bog and Swamp Peatlands in Quebec, Biogeochemistry, 11, 45-61, 1990

Moore, T. R., Bubier, J. L., Frolking, S. E., Lafleur, P. M., and Roulet, N. T.: Plant biomass and production and $\mathrm{CO}_{2}$ exchange in an ombrotrophic bog, J. Ecol., 90, 25-36, 2002.

Moore, T. R., Young, A., Bubier, J. L., Humphreys, E. R., Lafleur, P. M., and Roulet, N. T.: A Multi-Year Record of Methane Flux at the Mer Bleue Bog, Southern Canada, Ecosystems, 14, 646-657, 2011.

Nilsson, M., Mikkela, C., Sundh, I., Granberg, G., Svensson, B. H., and Ranneby, B.: Methane emission from Swedish mires: National and regional budgets and dependence on mire vegetation, J. Geophys. Res.-Atmos., 106, 20847-20860, 2001.

Nouchi, I. and Mariko, S.: Mechanism of methane transport by rice plants, edited by: Oremland, R.S., in: Biogeochemistry of Global Changes, Chapman \& Hall, New York, 336-352, 1993.

Pelletier, L., Moore, T. R., Roulet, N. T., Garneau, M., and Beaulieu-Audy, V.: Methane fluxes from three peatlands in the La Grande River watershed, James Bay lowland, Canada, J. Geophys. Res.-Biogeo., 112, G01018, doi:10.1029/2006JG000216, 2007.

Riordan, B., Verbyla, D., and McGuire, A. D.: Shrinking ponds in subarctic Alaska based on 1950-2002 remotely sensed images, J. Geophys. Res.-Biogeo., 111, G04002, doi:10.1029/2005JG000150, 2006.

Roulet, N. T., Ash, R., Quinton, W., and Moore, T.: Methane Flux from Drained Northern Peatlands - Effect of a Persistent WaterTable Lowering on Flux, Global Biogeochem. Cy., 7, 749-769, 1993.

Rydin, H. and Jeglum, J.: The Biology of Peatlands, Oxford University Press, New York, 2006.

Sheppard, S. K., Beckmann, M., and Lloyd, D.: The effect of temperature on methane dynamics in soil and peat cores: Calcula- 
tions from membrane inlet mass spectrometry, Can. J. Soil Sci., 87, 11-22, 2007.

Smith, L. C., Sheng, Y., MacDonald, G. M., and Hinzman, L. D.: Disappearing Arctic lakes, Science, 308, 1429-1429, 2005.

Song, C. C., Xu, X. F., Tian, H. Q., and Wang, Y. Y.: Ecosystematmosphere exchange of $\mathrm{CH}_{4}$ and $\mathrm{N}_{2} \mathrm{O}$ and ecosystem respiration in wetlands in the Sanjiang Plain, Northeastern China, Global Change Biol., 15, 692-705, 2009.

Song, C., Wang, X., and Miao, Y.: Effects of permafrost thawing on $\mathrm{CH}_{4}$ and $\mathrm{CO}_{2}$ emissions of peatland soils in the Great Hing'an Mountaions, China, in review, 2012.

Ström, L., Tagesson, T., Mastepanov, M., and Christensen, T. R.: Presence of Eriophorum scheuchzeri enhances substrate availability and methane emission in an Arctic wetland, Soil Biol. Biochem., 45, 61-70, 2011.

Sun, X., Mu, C., and Song, C.: Seasonal and spatial variations of methane emissions from montane wetlands in Northeast China, Atmos. Environ., 45, 1809-1816, 2011.

Tang, X., Liu, S., Zhou, G., Zhang, D., and Zhou, C.: Soilatmospheric exchange of $\mathrm{CO}_{2}, \mathrm{CH}_{4}$, and $\mathrm{N}_{2} \mathrm{O}$ in three subtropical forest ecosystems in southern China, Global Change Biol., 12, 546-560, 2006.

Turetsky, M. R., Wieder, R. K., Vitt, D. H., Evans, R. J., and Scott, K. D.: The disappearance of relict permafrost in boreal north America: Effects on peatland carbon storage and fluxes, Global Change Biol., 13, 1922-1934, 2007.

van Huissteden, J., Maximov, T. C., and Dolman, A. J.: High methane flux from an arctic floodplain (Indigirka lowlands, eastern Siberia), J. Geophys. Res.-Biogeo., 110, G02002, doi:10.1029/2005JG000010, 2005.
Wagner, D., Gattinger, A., Embacher, A., Pfeiffer, E. M., Schloter, M., and Lipski, A.: Methanogenic activity and biomass in Holocene permafrost deposits of the Lena Delta, Siberian Arctic and its implication for the global methane budge, Global Change Biol., 13, 1089-1099, 2007.

Wang, Y. S. and Wang, Y. H.: Quick measurement of $\mathrm{CH}_{4}, \mathrm{CO}_{2}$ and $\mathrm{N}_{2} \mathrm{O}$ emissions from a short-plant ecosystem, Adv. Atmos. Sci., 20, 842-844, 2003.

Whalen, S. C.: Biogeochemistry of methane exchange between natural wetlands and the atmosphere, Environ. Eng. Sci., 22, 73-94, 2005.

Wille, C., Kutzbach, L., Sachs, T., Wagner, D., and Pfeiffer, E. M.: Methane emission from Siberian arctic polygonal tundra: eddy covariance measurements and modeling, Global Change Biol., 14, 1395-1408, 2008.

Yavitt, J. B., Basiliko, N., Turetsky, M. R., and Hay, A. G.: Methanogenesis and methanogen diversity in three peatland types of the discontinuous permafrost zone, boreal western continental Canada, Geomicrobiol. J., 23, 641-651, 2006.

Zona, D., Oechel, W. C., Kochendorfer, J., U, Paw U, K. T., Salyuk, A. N., Olivas, P. C., Oberbauer, S. F., and Lipson, D. A.: Methane fluxes during the initiation of a large-scale water table manipulation experiment in the Alaskan Arctic tundra, Global Biogeochem Cy., 23, GB2013, doi:10.1029/2009GB003487, 2009. 